\title{
MEMORIAL TOURISM IN CROATIA? A CASE STUDY OF VUKOVAR: ATTITUDES OF LOCAL POPULATION
}

\author{
Klara Vukojević ${ }^{1}$ \\ Vuk Tvrtko Opačić ${ }^{2}$
}

\begin{abstract}
Croatian tourism supply is mainly based on Sun\&Sea tourism on the attractive coast and islands. However, in recent years there has been increased competition and the tourists' demands that have contributed to development of alternative forms of tourism, also in continental part of Croatia. The city of Vukovar, as the battlefield of one of the largest battles in Europe after the World War II, after its peaceful reintegration in the Croatian territory (1997), became the Croatian national memorial place. Even though tourism is not among the leading economy branches in Vukovar, due to its recent past, memorial tourism based on memorial sites from the Croatian Homeland War (1991-1995) could be developed. Memorial tourism is a form of cultural tourism with a supply based on memorial sites - places of important events, in this case the places of suffering and tragedies.

As main research objectives can be pointed out: a) the analysis of the characteristics of tourist flow and accommodation facilities in Vukovar after the end of the Croatian Homeland War and its reintegration into the Croatian territory and b) analysis of the Vukovar local population' attitudes on the possibilities of the development of memorial tourism based on heritage from the Croatian Homeland War. The local population attitudes were detected by a direct questionnaire survey at several locations in the center of Vukovar. In addition to descriptive statistics, statistical analyses were conducted to determine the differences in the respondents' attitudes (the dependent variable) with regard to gender, average age, level of education and nationality (independent variables). Total of eight statistically significant differences were found using standard statistical methods in SPSS program: chi-square test and t-test.
\end{abstract}

Key words: heritage, Croatian Homeland War, memorial tourism, dark tourism, memorial site, tourism development, Vukovar, Croatia

\section{INTRODUCTION}

Memorial tourism is rather new form of cultural tourism which entails visiting memorial sites, museums, sites of suffering and death, as well as monuments of important events with the goal of promoting the significance of events those places were dedicated to. Memorial tourism has a special effect on tourists and is based on emotions, shock and compassion. It has an educational purpose and upholds the importance of morality that is of great relevance in the modern world.

\footnotetext{
${ }^{1}$ Mag. educ. geogr. et hist., Elementary school "Ksaver Šandor Gjalski”, Mlinarska cesta 35, 10000 Zagreb, Croatia.

${ }^{2}$ Associate Professor, Department of Geography, Faculty of Science, University of Zagreb, Marulićev trg 19/II, 10000 Zagreb, Croatia.
} 
The term "dark tourism" is going to be used in this paper to refer to a form of memorial tourism related to death and tragedy that has the goal of provoking an emotional reaction and shock in the visitor, unlike its classic form that deals with solely depicting and interpreting events. Apart from "dark tourism", this form of tourism appears under different names in various literature, for example: "morbid tourism", "black tourism", "grief tourism", "tragedy tourism", "war tourism" (because dark tourism sites are frequently connected with war), "genocide tourism" or "extreme thanatourism" (Tang, 2014). It is important to point out that dark tourism is not based on death itself, but on certain forms of death and suffering which leave a strong impression on tourists.

The creators of the memorial and dark tourism theory are Lennon and Foley (1999). They published a series of papers related to this phenomenon, which in turn gave incentive to other authors to do the same. The great contribution in this area was made by Sharpley (2009). Other important papers were published by Knudsen (2011), Bavidge (2012), Chang (2014) and Korstanje (2015). The development of the idea to motivate people to partake in such events was given by Dunkley et al. (2011).

Dark tourism in its present form emerged in the mid $20^{\text {th }}$ century as a result of the increase in supply and demand in the tourism market (Bavidge, 2012). Its most important settings are related to war, suffering and death. Aesthetically speaking, those sites are usually not pleasant, however as monuments to living memories in a touristic sense they are very attractive, for example - Auschwitz (Poland), Gallipoli peninsula (Turkey), Normandy (France), the Italian Front from World War I in Kobarid (Slovenia; Klemenčič and Koderman, 2005) or Hiroshima (Japan). On the other hand, its setting can be an institution that gives the visitor an experience of being in the war affected area, even though it is miles away.

Experts agree that special care should be practiced when dealing with dark tourism sites and its interpretations to avoid provoking unwanted reactions in tourists (Stone, 2012). The proof of its growing popularity lies in the fact that, apart from being a form of tourism, it is becoming a tool of promotion, which is evident in extremely popular internet sites, such as thecabinet.com, which provide lists of the most popular dark tourism sites across the world and has many followers (Sharpley, 2009).

After Croatia declared independence from Yugoslavia in 1991, a Serbian offensive together with Yugoslav army with the goal of creating Great Serbia ensued. Large parts of Croatia were occupied and subsequently devastated, resulting in high casualty count. One of the greatest symbols of Croatian resistance and defense was the City of Vukovar, which eventually fell into enemy's hands on November $18^{\text {th }} 1991$ after 87 days of siege. More than 2,000 Croatian soldiers and civilians lost their lives, many prisoners were subsequently killed, the Croatian population was expelled from the city, and the city suffered enormous destruction (Croatian Encyclopaedia Online, 2016).

In the defensive Croatian War of Independence that lasted from 1991 to 1995, known in Croatia as the Croatian Homeland War, Croatia regained control of most of its occupied territories. The Danube area, in which the City of Vukovar is located, was peacefully reintegrated in Croatian territory in 1997. Those events marked the end of the War in 
Croatia which in turn raised the question of managing the rich heritage brought on by the Croatian Homeland War that Croats value as an important part of their national identity. There have been a negligible number of papers in Croatia published on the topic of placing the Croatian Homeland War heritage in the tourism market. For example, Opačić (2006) discusses the Croatian Homeland War from a tourismgeographical aspect and claims it is the basis of memorial tourism in Vukovar and Croatia. There have been few papers published on the topic of tourism in Vukovar and its surrounding areas, and they are mainly focused on descriptions of memorial tourism sites, which have lately been regarded as an opportunity to develop Vukovar's tourism, even though the potential supply has not been fully developed. Not even the "Tourism development strategy of Vukovar-Srijem County 2015-2020" deals with the topic in greater depth.

After its reintegration to Croatia in 1997, the City of Vukovar became a national memorial site as the setting of one of the largest battles in Europe after World War II. To Croats, Vukovar is a symbol of statehood, resistance, pain, suffering, compassion, courage and interpersonal solidarity. With adequate identification, interpretation and evaluation, Vukovar could touristically validate the memorial sites related to the events from the Croatian Homeland War and become a memorial tourism destination of international significance. The tourism supply of Vukovar and other parts of continental Croatia could be enriched with new memorial tourism products, contributing to a more balanced spatial development of tourism in Croatia.

\section{RESEARCH SCOPE AND METHODOLOGY}

The purpose of the research is to provide scientific contribution to the study of memorial tourism' developmental possibilities in Vukovar based on memorial sites from the Croatian Homeland War. Main research objectives are following:

- the analysis of the characteristics of tourist flow and accommodation facilities in Vukovar after the end of the Croatian Homeland War and its reintegration into the Croatian territory. The documents that are taken into account are the official statistics for the period 2000-2015 with particular emphasis on the year 2015.

- the analysis of the Vukovar local population' attitudes on the possibilities of the development of memorial tourism based on heritage from the Croatian Homeland War.

The study is based on the hypothesis that Vukovar has a large, so far unexplored, potential for memorial tourism development whose possibilities are recognized by the locals. They are based on the premises that Vukovar was a heroic city in the defense of Croatia during the Croatian Homeland War, but also as the battlefield of one of the largest battles in Europe after the World War II.

The local population' attitudes in Vukovar on the possibilities of the memorial tourism development based on the Croatian Homeland War heritage were detected by a direct questionnaire survey in the period $2^{\text {nd }}-5^{\text {th }}$ September 2015 at several locations in the center of Vukovar. The population of respondents consisted of adult residents of 
Vukovar. Convenience sampling covered a total of 81 respondents and survey questions were related to: socio-demographic characteristics (Table 1), the views of respondents on the current state of tourism in Vukovar and attitudes on (potential) tourism attractiveness of memorial sites from the Croatian Homeland War, as well as possibilities for memorial tourism development in the future and the willingness for respondents' personal involvement in memorial tourism development.

Table 1. Socio-demographic characteristics of the respondents

\begin{tabular}{|c|l|r|}
\hline \multicolumn{2}{|c|}{ SAMPLE CHARACTERISTICS } & \multicolumn{1}{|c|}{ TOTAL (N=81) } \\
\hline \multirow{2}{*}{ Gender $(\%)$} & Male & 56.8 \\
\cline { 2 - 3 } & Female & 43.2 \\
\hline Average age & & $39.1(\mathrm{SD}=13.652)$ \\
\hline \multirow{3}{*}{ Level of education (\%) } & Primary school & 3.7 \\
\cline { 2 - 3 } & High school & 23.5 \\
\cline { 2 - 3 } & College & 16.0 \\
\cline { 2 - 3 } & University and higher $(\mathrm{PhD})$ & 70.4 \\
\hline \multirow{3}{*}{ Nationality $(\boldsymbol{\%})$} & Croats & 21.0 \\
\cline { 2 - 3 } & Serbs & 8.6 \\
\cline { 2 - 3 } & Others & \\
\hline
\end{tabular}

It is evident that in the total sample of 81 respondents men are more represented than women, the average respondents age is slightly lower than 40, that more than half of respondents have secondary-level education and that in the ethnic structure Croats prevail with more than two-thirds ahead Serbs and others (Ruthenians, Ukrainians, Albanians, Macedonians, Slovaks). Topic of the research is very sensitive and that's why convenience sampling was used, which means that sample is not representative of total population in Vukovar ( $\mathrm{N}=26,468$ according to 2011 Census). The number of respondents in subsamples is adequate for conducting proposed analyses. This research is a sort of a pilot-study with intention to get an idea how research topic and questionnaire function in this local context., which opens perspectives for further, broader research. Regardless the fact that sample is not representative, research results demonstrate some clear differences in local population attitudes.

In addition to descriptive statistics (mean and frequency responses), statistical analyses were conducted in SPSS program to determine the difference in the respondents' attitudes (the dependent variable) with regard to gender, average age, level of education and nationality (independent variable) using standard statistical methods: the chi-square test and t-test.

\section{TOURISM IN VUKOVAR}

The tourist flow in Vukovar is relatively small when compared to the country's coastal area, or even to Vukovar-Srijem County itself. According to the data for 2014, out of 
93,702 nights spent in Vukovar-Srijem County, Vukovar amounted to only 11,913 which are $12.7 \%$. Ever since 2000 the number of tourist arrivals has been fluctuating, and a notable increase has been recorded in 2006. According to The City of Vukovar Tourist Board Data (2016), the tourist flow reached its peak between 2007 and 2010. Due to the economic crisis in Croatia, the tourist flow stagnated between 2011 and 2012, after which it showed a significant increase in the number of nights spent in 2013, only to be reduced again in 2014. In the following 2015, the number of tourist arrivals and nights have more than doubled, and in the first five months of 2016, there have been more tourist arrivals than in entire 2014 (Fig. 1). Due to the law of small numbers, the conclusions based on the interpretation of official tourist flow statistics for Vukovar are to be taken with a grain of salt because they greatly depend on the availability of limited accommodation capacities in the city.

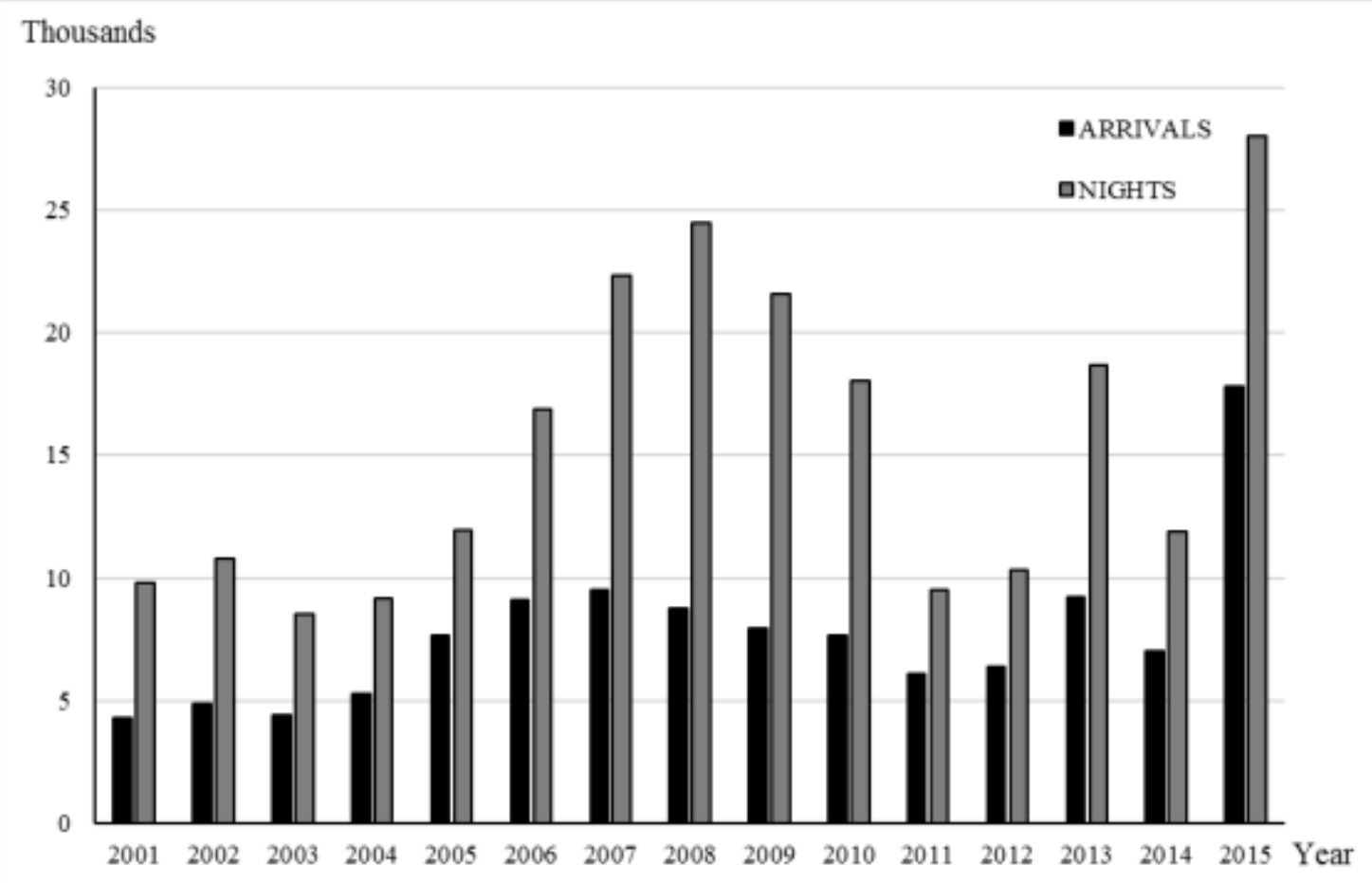

Fig. 1. Tourist arrivals and nights spent in the City of Vukovar in the period from 2000 to 2015

Source: Croatian Bureau of Statistics, 2016

The tourist arrivals structure is dominated by domestic tourists, and the increase in the number of tourists in 2015 and 2016 is the result of Croatian Government act making a two-day visit to Vukovar compulsory to elementary school students on their final year as a part of the Homeland War education (Table 2). 
Table 2. Tourist arrivals in Vukovar from 2013 to 2016

\begin{tabular}{|l|c|c|c|c|}
\hline TOURIST ARRIVALS & $\mathbf{2 0 1 3}$ & $\mathbf{2 0 1 4}$ & $\mathbf{2 0 1 5}$ & $\begin{array}{c}\mathbf{2 0 1 6} \\
\text { (January- } \\
\text { May) }\end{array}$ \\
\hline Foreign tourists & 3,552 & 2,594 & 3,293 & 1,262 \\
\hline Domestic tourists & 5,665 & 4,423 & 14,518 & 7,882 \\
\hline TOTAL & 9,217 & 7,017 & 17,811 & 9,144 \\
\hline
\end{tabular}

Source: Croatian Bureau of Statistics, 2016

The largest groups among foreign tourists in Vukovar are those from Germany and Italy, followed by tourists from neighboring countries - Serbia, Slovenia and Bosnia and Herzegovina. Tourists from the UK achieved also significant number of nights in 2015. The number of beds available in Vukovar is not great but still manages to satisfy the demand with the exception of the period when the Vukovar Film Festival is being held and on November $18^{\text {th }}$, the anniversary of the fall of Vukovar. There is only one hotel in Vukovar - "Hotel Lav" - situated in the city center on the Danube bank. It is a four star hotel and a congress center, with the capacity of 100 guests. According to The Vukovar Tourist Board data for July 2016, there are 17 lodgings available aside from the hotel - 3 hostels and 14 apartments and rooms for rent. All lodgings can simultaneously host 570 tourists (The City of Vukovar Tourist Board Data, 2016). Even though the accommodation capacity is very small and insufficient for stronger tourism development, it has to be pointed out that it is increasing. There are 7 new lodgings and number of beds is increased by about 130, compared to 2013 (The City of Vukovar Tourist Board Data, 2016). The statistics for 2014 have not been taken into account because the hotel "Borovo" with a high guest capacity functioned as a shelter for people who lost their homes in the flood that affected Eastern Croatia. The biggest deficiency in the city's accommodation capacity is the unused potential of the hotel "Dunav", the biggest lodging facility in the city in the period before the Croatian Homeland War, which ceased working after the War. The current state of the tourism supply, investments and the management of the memorial sites is not on the level which would turn tourism into one of the key economic branches in the city. There is a series of problems that stand in the way of tourism development - a meager engagement of The City of Vukovar Tourist Board, the focus of the local government on other economy branches, and the lack of cooperation between local population which should serve as a bottom-up trigger. The city's cultural supply is growing in quality every year, however management, marketing and creativity of the managers are not on the level they should be. Memorial tourism needs to be the main, but not the only form of tourism in Vukovar. The fact is that the Battle of Vukovar, as one of the largest battles in Europe after World War II, could attract many visitors with proper presentation and interpretation, but not keep them in the city for a longer period. Prolongation of tourists' stay could be achieved by developing other forms of tourism the city could offer, such as classic culture tourism, rural tourism, gastro tourism, wine tourism and 
sports tourism. Vučedol Culture Museum plays an important role in the city's tourism supply as a contemporary museum on a multilayer archaeological site which was populated from the Neolithic age to the Middle Ages.

There is a huge potential for developing memorial tourism based on the Croatian Homeland War sites. It is important to point out the "Memorial Vukovar" project (also named "Vukovar Nocturno" project) as the starting point of validating the memorial tourism sites. "Memorial Vukovar" is a joint name for a number of sites and museums dedicated to the Croatian Homeland War, its victims and The Battle of Vukovar. This project serves as a reminder and a warning of the suffering war entails, and as a monument to victims of hate and inhumanity. It encompasses seven memorial sites in Vukovar: Place of Remembrance - The Vukovar Hospital ${ }^{1}$, The Memorial Home "Ovčara", Ovčara Mass Grave, The Memorial Cemetery of the Victims of the Croatian Homeland $\mathrm{War}^{2}$, The Memorial Center of the Croatian Homeland War ${ }^{3}$, The Memorial Center of Croatian Defenders - Trpinjska Street and The Central Cross on the mouth of the Vuka river ${ }^{4}$.

These seven landmarks have been touristically arranged to familiarize the visitors with the events dating back to 1991 . There are more potentially appealing memorial sites in the city and its surrounding area, but they are yet to be included in the Project. Of the aforementioned sights, the most visited in 2014 were The Memorial Center of Croatian Defenders - the sight of heavy resistance to tank attacks, and "Ovčara" - the sight of mass torture and execution of Vukovar's prisoners (City of Vukovar Tourist Board, 2016).

The visits to those sites mainly comprise of school excursions and the annual procession on the anniversary of the fall of Vukovar on November $18^{\text {th }}$. That period is characterized by a slight increase in visitor count, but during the rest of the year (with the exception of the Vukovar Film Festival) Vukovar is a city with few tourists on Croatia's periphery. The city's cultural supply such as cultural institutions, objects and manifestations is very well developed, but without proper marketing it cannot attract foreign tourists to choose Vukovar as a targeted destination.

\footnotetext{
${ }^{1}$ Part of hospital which was bombed on daily basis, full of injured civilians and soldiers, today converted into museum

${ }^{2}$ Memorial cemetery at the location of a mass grave form Croatian Homeland War

${ }^{3}$ Former military barrack converted into museum

${ }^{4}$ Cross set up on the mouth of the Vuka river in honor of the victims of the Croatian Homeland War
} 


\section{LOCAL POPULATION ATTITUDES ON THE POSSIBILITY OF MEMORIAL TOURISM DEVELOPMENT IN VUKOVAR}

\section{Descriptive statistics analysis results}

Half $(50.6 \%)$ of respondents mostly or completely agree with the statement that tourism in Vukovar is an important economic branch today, and even $81.5 \%$ of respondents believe that tourism can be an important factor in the future economic development of Vukovar. Questioned to name the three forms of tourism that should be developed in Vukovar, most respondents pointed out: memorial tourism, followed by cultural tourism, rural tourism, recreational tourism, summer holiday river tourism and cruising tourism. However, most respondents (35.8\%) don't have any positive or negative attitude regarding the statement that the memorial tourism is the most appropriate tourism form in the future development of tourism in the city. However, more respondents estimate that this form of tourism would be most appropriate in the further development of tourism supply $(27.2 \%$ of respondents completely agrees with the previous statement, and $24.7 \%$ generally agrees).

Only $12.3 \%$ believe that memorial tourism is not and should not be the mainstay of the tourism supply, mostly because of the negative connotations that association on any war has on certain number of tourists. The latter group of respondents pointed out that the city has other tourism attractions and that they would fall into the background if stronger tourism valorization of Croatian Homeland War memorial sites would take place. It could also negatively contribute to the tourism image of Vukovar and consequently on overall tourism development.

Descriptive statistics is showing that Croats as well as ethnic minorities in Vukovar, do not share the same view with the Serbs in terms of the perspective on the memorial tourism development based on heritage from the Croatian Homeland War.

The same conclusion follows from the answer to the question in which respondents named three locations in Vukovar, which they consider to have the greatest tourism attractiveness. Although the majority of respondents rank memorial sites from the War (The Memorial Home "Ovčara" together with Ovčara Mass Grave, The Water Tower, The Memorial Cemetery of the Victims of the Croatian Homeland War, The Vukovar Hospital, The Central Cross at the mouth of Vuka river) among the most attractive locations in the city (alongside with the archaeological site Vučedol, City Museum, Ada - the Danube island, Forest park Adica, Castle Eltz, the baroque city center), respondents of Serbian ethnic minority as a tourism attraction didn't highlight any War memorial site. The exception is only The Water Tower, which could not be classified among the sites whose tourism attractiveness stems solely from the War due to its prewar recreational function (including panoramic restaurant on the top floor).

The respondents rated from 1 (lowest tourism attractiveness) to 5 (highest tourism attractiveness) tourism attractiveness of memorial sites from the War involved in "Memorial Vukovar" project (Fig. 2). 


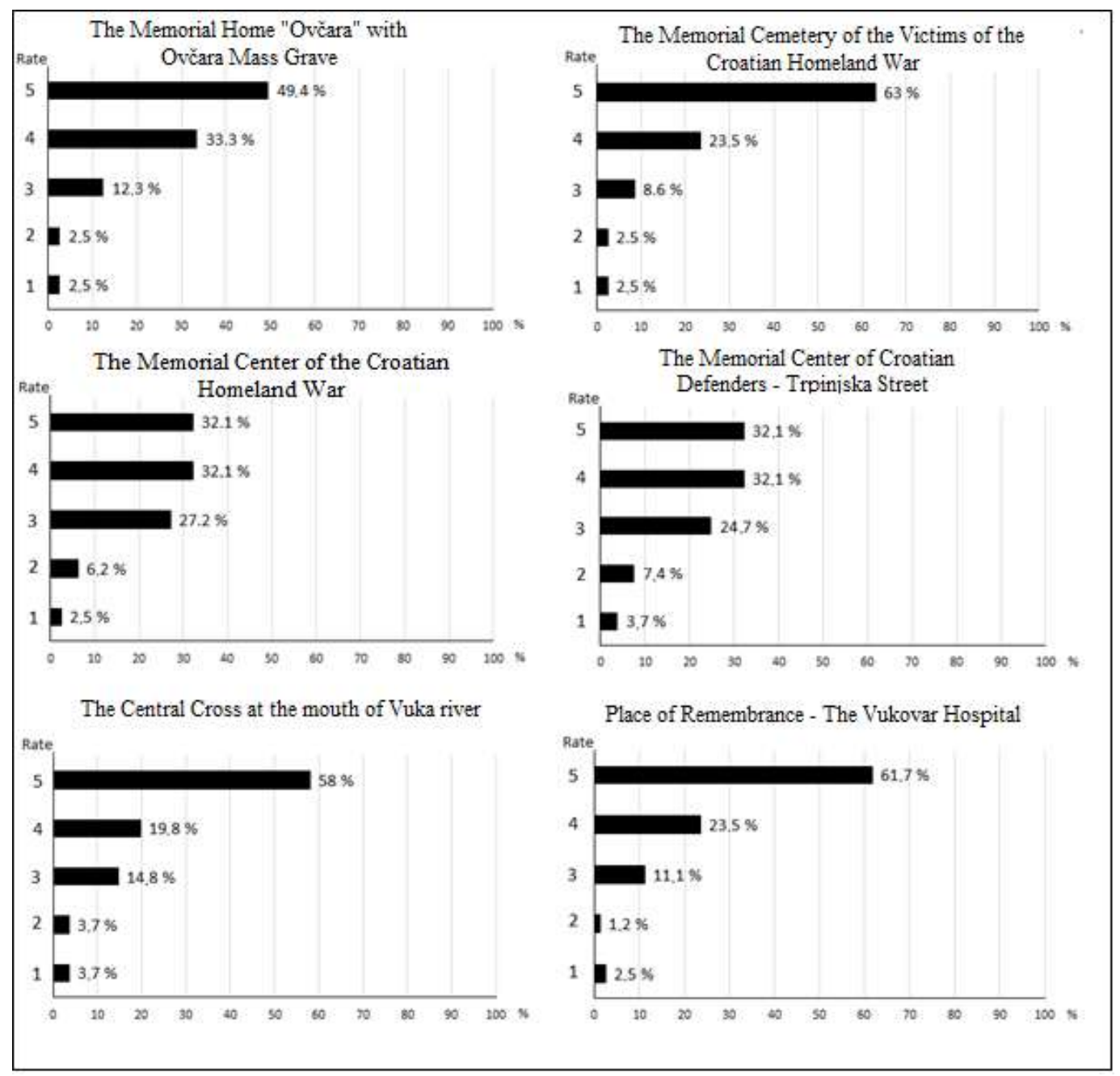

Fig. 2. Evaluation of tourism attractiveness of the memorial sites involved in "Memorial Vukovar" project

Tourism attractiveness of all these memorial sites was highly rated by most respondents. The highest rating received The Memorial Cemetery of the Victims of the Croatian Homeland War, followed by The Vukovar Hospital and The Central Cross. Among other potentially attractive memorial sites, which are not included in "Memorial Vukovar" project, most respondents recognized "Borovo Commerce" - civic shelter during the siege of the city, which served as an auxiliary hospital and later after its occupation became a place of civil suffering, hangar "Velepromet", which served as a concentration camp similar to Ovčara, The Water Tower, a symbol of the defense of the city, and "Corn Path" or "Path of Salvation" - the shortest way for Croatian soldiers who came to defend the city.

As the biggest obstacle for tourism development in Vukovar respondents name political disputes (even 48.1\%). The lack of cooperation among local population is considered to 
be an obstacle by $21.0 \%$ of respondents, while $14.8 \%$ of them as an obstacle highlight lack of accommodation facilities. Only $1.2 \%$ of respondents believe that the biggest obstacle in the Vukovar tourism development is lack of cultural supply. Other obstacles mentioned by the respondents were: non-cooperation of the Vukovar Tourist Board and the local government, the disconnection of certain tourist sites with lack of specific tourism itineraries, the ineffectiveness of the Tourist Board, the mentality of the population, youth leaving the city and corruption.

The majority of respondents $(55.6 \%)$ believe that the lack of accommodation facilities in the city could be most successfully solved with the renewal of the hotel "Dunav". Other possible solutions respondents have chosen in the following proportions: giving incentives to locals for opening private accommodation facilities $(19.8 \%)$, construction of special accommodation facilities for students from all over Croatia (13.6\%). None of the respondents hasn't chose the answer that the current lack of accommodation facilities in the city could be best solved by building another hotel with (too) high categorization and modeled on the existing hotel "Lav".

This confirms the awareness of the local community in terms of positioning Vukovar as a weekend destination in which convention hotels with four or five stars cannot be carriers of accommodation supply.

Among the major shortcomings in the development of the memorial tourism respondents identified: disconnection among institutions (Museum - Tourist Board local government) $(29.6 \%)$ and poor marketing $(28.4 \%)$ which is governed by the Tourist Board, museums and local tourist agencies. Tourism inequipment, including lack of road signs, tourist guides and facilities available in English and German is identified as a limitation by $16.0 \%$ of respondents, while bad management of some sites as the biggest drawback is emphasized by $14.8 \%$. Other disadvantages that respondents reported were: a relatively large distance between the memorial tourism sites, but also their inappropriate working hours and passive mentality of the population.

The local public is quite divided regarding the main target group for which the tourism product of memorial tourism based on the Croatian Homeland War should be primarily intended. An equal number of respondents (45.7\%) considers that it should be offered and accordingly interpreted for younger tourists (children, students), as well as for all visitors (not only tourists) of mature age. Only 6.2\% of respondents consider that the main interest group for the memorial tourism supply in Vukovar should be elderly tourists.

Most respondents believe that the interpretation and presentation of memorial sites from the War should be primarily customized for foreign tourists (69.1\%). Just over a quarter of respondents $(28.4 \%)$ believes that tourist facilities should be adjust for the interest of Croatian tourists, while $2.5 \%$ of respondents consider that interpretation and presentation should equally be focused on the interest of local and foreign tourists. The prevailing attitude is that there is a potential market value of the memorial tourism product, and in the future it should be intended mainly to foreign tourists. This is 
additionally supported by previously presented attitude that memorial tourism has a key role in future tourism development of Vukovar.

As the most responsible stakeholders for the improvement of tourism supply of Vukovar as a destination, respondents primarily recognize: local government $(35.8 \%)$, followed by the Tourist Board of Vukovar (33.3\%), Vukovar-Srijem County (13.6\%), local travel agencies $(6.2 \%)$, while only $4.9 \%$ of respondents pointed out the local population. This result confirms that general support of the local community for stronger tourism development exists, but it has a passive character.

The latter is somewhat confirmed by the respondents answers on a scale of 1 (minimum value) to 5 (the highest value) assessing their readiness to engage personally in the future memorial tourism development in the city. Most respondents are ready to personally engage (grade 5 and grade 4 on the scale $-54.3 \%$ of respondents), and they are followed by those who are moderately motivated to actively participate in the future development of the memorial tourism (score from 3 to $27.2 \%$ of respondents).

However, this support seems to be only declaratively pronounced because the opinion "I alone cannot do anything" prevails, which is a major problem in the development of the memorial tourism and other forms of tourism. Many respondents articulated a clear attitudes regarding further tourism development in the city, expressed by numerous ideas, but still demonstrate clearly passive behavior in terms of personal involvement.

The last question of the questionnaire gave an opportunity for respondents to think on their self-involvement in tourism development in Vukovar through ideas or specific activities.

Among the most common suggestions were: organization of more festivals and events, arrangement of places for young people and children, restoration of The Water Tower, renovation of the hotel "Dunav", the rearrangement of the river Vuka old riverbed in the promenade, promotion of recreational sport and sports competitions, greater valorization of the Danube and everything that the river provides, and youth involvement in various projects, e.g. through volunteering.

Many respondents pointed out that Vukovar should be more intensively promoted through social networks, that fishing and recreational tourism should be enhanced and facilities at the bathing place Ada should be improved. It would be important to link small craftsmen in creating tourism supply, to prolong cruiser tourists stay in Vukovar and offer them what they are currently looking for outside of the city (a rural tourism, mostly local wine and cuisine), arrange passenger harbor for cruisers.

It is interesting that there was no a single answer to this question associated with the memorial tourism development, which supports the conclusion that, although the local population is aware of its potential, yet still is not seen as a contemporary tourism product, and that this form of tourism in Vukovar is still in its beginnings. 


\section{The differences in perception with regard to gender, average age, level of education and nationality}

Total of eight statistically significant differences in local respondents' attitudes were found using standard statistical methods in SPSS program: chi-square test and t-test. Differences were found regarding gender (three statistically significant differences), the average age (one statistically significant difference) and nationality (four statistically significant differences). The only independent variable according to which there were no statistically significant differences in the respondents' attitudes was level of education. The level of agreement with the statement that tourism is an important branch of the economy in Vukovar was questioned using Likert-type scale where the score 1 indicated the lowest level of agreement, and the score 5 the highest. Statistically significant differences with the statement were found with regard to gender using t-test $(\mathrm{t}=-2.995 ; \mathrm{df}=79 ; \mathrm{p}=0.004)$. Women $(\mathrm{M}=3.83 ; \mathrm{SD}=1.071)$, in fact, have more positive attitude, than men $(\mathrm{M}=3.02 ; \mathrm{SD}=1.291)$, which can be explained by the fact that tourism is an economic activity in which men and women are equally employed, unlike some other activities (e.g. agriculture or industry) in which men are typically employed in larger numbers. Therefore women usually perceive importance of the tourism in the economic structure even higher than it is in reality, especially in areas, like Vukovar, where tourism is not developed to a greater extent.

Chi-square test revealed significant differences between respondents according to gender in the answer on three forms of tourism that should be developed in Vukovar $\left(\mathrm{X}^{2}=6.289 ; \mathrm{df}=1 ; \mathrm{p}=0.012\right)$. Of all respondents who have named memorial tourism among the three most important forms of tourism in future tourism supply, almost three quarters were men $(72.2 \%)$, while the share of women was $27.8 \%$. On the other hand, of those who favor other forms of tourism, $55.6 \%$ are women and $44.4 \%$ men. These differences according to gender in supporting the memorial or other forms of tourism can be explained by the fact that men were more actively engaged in the defense of the city during the War and personal emotional attitude towards the memorial sites could be stronger than for women. The War is in general an event with which men, due to more active participation and personal experience, identify themselves more than women, and consequently attach greater value towards memorial sites and heritage.

Chi-square test revealed significant differences between respondents according to gender on the answer about the biggest obstacle to tourism development in Vukovar $\left(\mathrm{X}^{2}\right.$ $=7.738 ; \mathrm{df}=2 ; \mathrm{p}=0.021)$. Men emphasized more often the lack of cooperation among local population ( $76.5 \%$ men and $23.5 \%$ women chose this answer), while women emphasized more often lack of accommodation facilities as the biggest obstacle $(75.0 \%$ women and $25.0 \%$ men chose this answer). The findings could be explained by the fact that men are more concerned with political and social relations, especially in postconflict environments. Using the t-test, differences in opinion for whom interpretation and presentation of memorial sites should be primarily adjusted, were found with regard to the respondents' average age $(t=2.640 ; d f=77 ; \mathrm{p}=0.010)$. Respondents who think 
that it should be more oriented towards locals and visitors, and not just tourists, are in average older $(\mathrm{M}=45.43$; $\mathrm{SD}=13.760)$, while respondents who believe that it should be more oriented to foreign tourists are in average younger $(\mathrm{M}=36.79$; $\mathrm{SD}=13.013)$. From the above differences in attitude with regard to age it could be concluded that the older residents of Vukovar recognize memorial sites from the War primarily as an important part of national as well as personal heritage, and only afterwards as a (potential) tourism attraction. On the other hand, younger respondents also acknowledge the heritage value that should be preserved and, but more as a tourism attraction. The differences in attitude can be explained by deeper feelings towards these localities within an elderly population that actively participated in the Croatian Homeland War. In addition, today's era of consumerism and the commodification of a large number of available goods in the market products is more accepted within younger generation and this is not surprising having in mind adverse economic prospects for young people in Vukovar. Chi-square test revealed significant differences between Croats and Serbs in the answer regarding three forms of tourism that should be developed in Vukovar $\left(\mathrm{X}^{2}=15.911\right.$; $\left.\mathrm{df}=1, \mathrm{p}=0.000\right)$. All respondents who mentioned memorial tourism among the three most important forms of future tourism supply were Croats $(100.0 \%)$. Of those who prefer other forms of tourism, $60.5 \%$ were Croats (since their ratio in total sample was higher), and $39.5 \%$ of Serbs. Statistically significant differences between Croatian and Serbian respondents were found in the agreement with the statement associated with the memorial tourism, and in assessing their readiness to cooperate in the development of the memorial tourism in Vukovar using ttest (Table 3). The degree of agreement was tested using a Likert-type scale where the score 1 indicated the lowest level, and 5 the highest level of agreement. This statement was: "Memorial tourism is the most appropriate form of tourism for tourism development of Vukovar", and a question that referred to the willingness for cooperation was "In what extent you are willing to cooperate in the development of the memorial tourism?"

Table 3. The level of agreement with the statement associated with the memorial tourism and rating personal willingness to cooperate in the memorial tourism development in Vukovar

\begin{tabular}{|c|c|c|c|c|c|}
\hline \multirow{2}{*}{$\begin{array}{c}\text { THE LEVEL OF AGREEMENT WITH } \\
\text { THE STATEMENT/RATING } \\
\text { PERSONAL WILLINGNESS TO } \\
\text { COOPERATE }\end{array}$} & \multicolumn{2}{|c|}{ CROATS } & \multicolumn{2}{|c|}{ SERBS } & \multirow[b]{2}{*}{ T-TEST } \\
\hline & $\mathbf{M}$ & SD & $\mathbf{M}$ & SD & \\
\hline $\begin{array}{l}\text { Memorial tourism is the most appropriate } \\
\text { form of tourism for tourism development of } \\
\text { Vukovar. }\end{array}$ & 3.89 & 0.939 & 2.59 & 1.228 & $\begin{array}{l}t=4.680 \\
d f=72 \\
p=0.000\end{array}$ \\
\hline $\begin{array}{l}\text { In what extent you are willing to cooperate } \\
\text { in the development of the memorial } \\
\text { tourism? }\end{array}$ & 3.93 & 1.223 & 2.41 & 1.278 & $\begin{array}{l}\mathrm{t}=4.448 \\
\mathrm{df}=72 \\
\mathrm{p}=0.000\end{array}$ \\
\hline
\end{tabular}


Using the t-test, differences with regard to nationality were identified in choosing three locations in Vukovar considered to have a tourism attractiveness $(\mathrm{t}=2.734$; $\mathrm{df}=72 ; \mathrm{p}=$ 0.008). The question was open-ended, and respondents could indicate any of three locations in the city that are attractive for the tourists. So, among the three mentioned localities, it was possible to name a maximum of three and a minimum of zero memorial sites from the War. While Croats on average mentioned more than one memorial sites $(M=1.16$; $\mathrm{SD}=0.882)$, Serbs recognized twice less memorial sites as attractive for tourists $(\mathrm{M}=0.53$; $\mathrm{SD}=0.624)$. In the previous descriptive results interpretation it was already pointed out that The Water Tower is the only site that could be partially counted as the memorial site and that is also for Serbian respondents touristically attractive.

Statistically significant differences in the attitudes among Croatian and Serbian respondents regarding importance and prospects of memorial tourism development based on heritage from the War in Vukovar clearly indicate different perceptions of memorial sites from the War, as it is the case with perception of War in general. Although the life of Croats and Serbs in Vukovar today is much more connected and more peaceful compared to tensions ten or fifteen years ago, different views of the War and its legacy still exists, which is not surprising considering that the members of these two nations were on the opposing sides in the War. While such differences may be a challenge in a stronger development of the memorial tourism in Vukovar, they could be overcome if the memorial tourism stimulates stronger growth of other forms of tourism. This goal is pronounced by city residents, regardless of nationality (e.g. cultural tourism, rural tourism, sports recreational tourism, summer holiday river tourism, and cruising tourism), and this could contribute to positioning Vukovar as a unique international tourism destination.

\section{CONCLUSION}

The pre-war tourism development in Vukovar was based on the prehistoric archaeological site Vučedol, Baroque cultural heritage and sports activities alongside the Danube. The visitors to these tourism attractions were mostly domestic tourists and local population. Industry and strong agriculture were the basis of Vukovar's economy, resulting in no need to develop tourism as one of its key branches. Following heavy destruction during the Croatian Homeland War and post-war reconstruction, the city has faced numerous social and economic issues, which are becoming an increasingly visible push factor, especially among younger population. As one solution (but not the only one), for to the revitalization of the city, the stronger tourism development is imposed, especially the memorial tourism. Numerous places of War sufferings, i.e. memorial sites in the city and surrounding area should have a first-class role in the tourism development. These places hold the indispensable potential to develop memorial tourism in Vukovar, which would differentiate its tourist supply from other destinations in Croatia. Based on the study, it can be concluded that the current 
situation in tourism in the city is modest, especially in terms of accommodation. On the other hand, the attractions to develop memorial and other forms of tourism are not lacking, and the cultural supply is richer year after year. Over the past few years there is a noticeable increase in tourist flow, especially among domestic tourists which is the result of the Croatian Ministry of Science, Education and Sports act making an excursion to Vukovar compulsory for elementary school students on their final year as a part of education on the Croatian Homeland War. Visit usually takes place within two days arrangement.

Research results have shown that local population sees great potential in tourism as a tool for future economic development of Vukovar. Thus, the majority of the population, with the exception of the Serbian minority, stresses the primary importance of the memorial tourism based on memorial sites from the War as the most attractive tourist product, particularly for foreign tourists. This supports the thesis that local population, especially of younger age, realizes the importance of branding Vukovar as a memorial tourism destination not only for domestic, but for foreign tourists as well. The tourism products of other forms of tourism, such as cultural tourism, rural tourism, sports tourism, summer holiday river tourism or cruising tourism, are perceived as a supplement by the locals.

Among the other attractions, the greatest potential to attract foreign tourists shows contemporary designed Vučedol Culture Museum (opened in 2015) at the famous archaeological site and it could be linked with the memorial tourism supply. Research has shown that local population sees political disagreements, the lack of cooperation among governing institutions and a passive mentality as the main obstacles to the city's tourism development. In the past years, a project of reconstruction of The Water Tower called "Water Tower - symbol of Croatian unity" started, aiming to renovate one of the symbols of the city's defense and whose implementation will enrich the tourism supply. The memorial sites need to be thematically connected in a "route of memorial heritage", (for example by bicycle trails) and branded as a unique tourism product. Aside from the attractions themselves, investments in marketing and better cooperation with foreign tourist agencies, especially the ones offering Danube cruises, are needed to successfully turn Vukovar into a memorial tourism destination.

This would give a touristic value to the city's favorable geographic position on the Danube river as the seventh Pan-European traffic corridor. It can be concluded that successful development of the memorial tourism in Croatia based on the Croatian Homeland War heritage requires objective identification, evaluation, interpretation and finally tourism valorization of memorial sites. In this process, an objective approach is required in order to emphasize, apart from unquestionable historic and emotional value for Croats, their tourist potential to attract foreign tourists. 


\section{REFERENCES}

1. Bavidge, E. (2012). The „when“ of memory: Contemporary memorials to distant and violent pasts. International Journal of Cultural Studies, 16 (4), 315-334.

2. Chang, T. (2014). Dark Tourism: The Effects of Motivation and Environmental Attitudes on the Benefits of Experience. Revista Internacional de Sociologia (RIS), $72(2), 69-86$.

3. City of Vukovar Tourist Board http://www.turizamvukovar.hr/index.php?stranica $=37$, (July $\left.11^{\text {th }} 2016\right)$

(2016).

4. Croatian Bureau of Statistics (2016). http://www.dzs.hr, (July 11 ${ }^{\text {th }} 2016$ )

5. Croatian Encyclopaedia Online (2016), (ed. Ravlić, S.), article "Vukovar". The "Miroslav Krleža" Institute of Lexicography, Zagreb. $\mathrm{http}: / /$ www.enciklopedija.hr/natuknica.aspx $? \mathrm{id}=65649$, (July $\left.11^{\text {th }} 2016\right)$

6. Dunkley, R., Morgan, N., Westwood, S. (2011). Visiting the trenches: Exploring meanings and motivations in battlefield tourism. Tourism management, 32 (4), 860 -868 .

7. Knudsen, T.B. (2011). Thanatourism: Witnessing Difficult Pasts. Tourist Studies, 11 (1), 55-72.

8. Klemenčič, M, Koderman, M. (2015). The Isonzo/Soča Front and Its Potentials for Development of Tourism. In: Dark Tourism: Post WWI Destinations of Human Tragedies and Opportunities for Tourism Development: proceedings of the international workshop (eds. Gosar, A., Koderman, M., Rodela, M.). University of Primorska Press, Koper, 45-51.

9. Korstanje, M. (2015). The anthropology of dark tourism: Exploring the contradiction of capitalism. Centre for Ethnicity \& Racism Studies (http://cers.leeds.ac.uk/files/2015/02/Korstanje_CERS_15.pdf)

10. Lennon, J.J., Foley, M. (1999). Interpretation of Unimaginable: The U.S. Memorial Museum, Washington D.C., and „Dark Tourism“. Journal of Travel Research, 4650 .

11. Opačić. V.T. (2006). Domovinski rat kao osnova razvoja memorijalnog turizma Hrvatske?! In: Geografija.hr offline 2003-2005. (ed. Lukić, A.). Hrvatsko geografsko društvo, Zagreb, 30-35.

12. Sharpley, R. (2009). Shedding Light on Dark Tourism: An Introduction. In: The Darker Side of Travel: The Theory and Practice of Dark Tourism (ed. Sharpley, R., Stone, R.P.). Channel View Publications, Bristol, 3-22.

13. Stone, R.P. (2012). Dark Tourism and Significant other Death: Towards a Model of Mortality Mediation. Annals of Tourism Research, 39 (3), 1565-1587.

14. Tang, Y. (2014). Dark Touristic Perception: Motivation, Experience and Benefits Interpreted from the Visit to Seismic Memorial Sites i Sichuan Province. Journal of Mountain Science 11 (5), 1326 - 1341.

15. The City of Vukovar Tourist Board Data (2016) 
16. Tourism development strategy of Vukovar-Srijem County 2015-2020 (2015). Vukovar-Srijem County, Vukovar. 